\title{
Role of Microbes in Petroleum Hydrocarbon Degradation in the Aquatic Environment: A Review
}

\author{
David Waikhom $^{1 *}$, Soibam Ngasotter ${ }^{1}$, Laishram Soniya Devi ${ }^{2}$, \\ Manoharmayum Shaya Devi ${ }^{3}$ and Asem Sanjit Singh ${ }^{2}$ \\ ${ }^{1}$ College of Fisheries, Central Agricultural University (Imphal), \\ Lembucherra, Tripura-799210, India \\ ${ }^{3}$ ICAR-Central Inland Fisheries Research Institute (CIFRI), Barrackpore-700120, India \\ ${ }^{2}$ ICAR-Central Institute of Fisheries Education (CIFE), Mumbai-400061, India
}

*Corresponding author

\begin{tabular}{l} 
Ke y w o r d s \\
$\begin{array}{l}\text { Enzymes, Microbial } \\
\text { degradation, Oil } \\
\text { spill, Petroleum } \\
\text { hydrocarbon }\end{array}$ \\
\hline Article Info \\
$\begin{array}{l}\text { Accepted: } \\
\text { 23 April } 2020 \\
\text { Available Online: } \\
\text { 10 May } 2020\end{array}$ \\
\hline
\end{tabular}

\section{A B S T R A C T}

The phenomenon of the oil spill in the marine ecosystem is one of the major issues which causes the introduction of petroleum hydrocarbon pollutants and leads to a significant threat to the environment. It can occur either naturally or from anthropogenic sources such as those caused by tanker accidents, refineries, drilling operations, or even storage facilities. This causes significant damage to both the habitat and the organisms living in the marine environment. Bioremediation by oildegrading microorganisms is a viable option to metabolize and remove these harmful pollutants from the polluted site. Oil degrading microorganisms are ubiquitously distributed in the environment and naturally biodegrade petroleum hydrocarbon. This review highlights the mechanism of microbial degradation of petroleum hydrocarbons by enzyme catalytic activities of microorganisms to increase the rate of petroleum hydrocarbon degradation. It also highlights the factors that affect the biodegradation of petroleum hydrocarbons by the microorganisms.

\section{Introduction}

Oil pollution has been one of the major challenges to fight climate change in the world, particularly the aquatic marine ecosystem. The increase in pollution is a threat to the marine ecosystem and it also alters the balance of both the habitat and the organisms that live there. These organisms experience altered growth and reproduction patterns, anatomical complications, and increased susceptibility to hypothermia.

The majority of the oil pollution relates to the large numbers of spills, both large and small, being recorded every year. The impact on the environment in response to oil pollution with geographical isolation and extreme 
conditions, making any response logistically challenging. The Gulf War oil spill of Kuwait is the largest marine oil spill in the world (Abbriano et al., 2011) that significantly threat to the marine environment. It was estimated that the Exxon Valdez oil spill of 1989 and Deepwater Horizon (DWH) oil spill of 2010 discharged 11 million gallons of Alaskan North Slope crude oil and 4.9 million barrels of South Louisiana sweet crude oil into the Gulf of Mexico respectively resulting in huge contribution in term of polluting the marine ecosystem (Bragg et al., 1994). There are different techniques for the removal of pollutants and the use of microbe is a viable option as compared to conventional physicochemical methods and became economically viable. This review will highlight the microbial degradation of petroleum hydrocarbon and also how the microbes interact with the environment regarding the mechanisms involved under aerobic conditions.

\section{Composition of petroleum hydrocarbon}

Recent advances in ultra-high-resolution mass spectrometry have allowed the identification of more than 17,000 distinct chemical components which made more complex and term as petroleomics. Crude oil can be classified into four main defined groups of chemicals: (a)the saturated hydrocarbons, (b) aromatic hydrocarbons, (c) the resins, and (d) the asphaltenes. Heavy oils contain lower saturated and aromatic hydrocarbons and a higher proportion of the more polar chemicals, the resins, and asphaltenes while light oils have higher aromatic and saturated hydrocarbons, with a smaller proportion of asphaltenes and resins. Under anoxic conditions, heavy oils result from the biodegradation of crude oil in situ in petroleum reservoirs. Due to the nature of more toxic and persistent nature, the aromatic hydrocarbons and polar fractions could be of greater long-term environmental significance (Head et al., 2006).

\section{Microbial degradation of petroleum hydrocarbons}

It has been identified that more than 79 genera of bacteria are capable to degrade petroleum hydrocarbons ( $\mathrm{Xu}$ et al., 2018). Several interesting marine bacteria that are adapted to hydrocarbon degradation have been isolated (Table 1). Hydrocarbon degrading bacteria include Alcanivorax spp., Cycloclasticus spp., Oleiphilus spp., Oleispira spp., Thalassolituus spp., Planomicrobium (formerly known as Planococcus) uses hydrocarbons exclusively as a carbon source. Alcanivorax spp., Oleiphilus spp., Oleispira spp., Thalassolituus spp. Planomicrobium alkanoclasticum MAE2 uses a variety of saturated hydrocarbons, however, Cycloclasticus spp. have evolved to use a range of polycyclic aromatic hydrocarbons(Head et al., 2006).Wide geographical distribution of Alcanivorax spp., particularly in oil spills may be due to their ability to use branched-chain alkanes more effectively than other hydrocarbon-degrading bacteria, giving these species a selective advantage. Branched-chain alkanes such as pristane enter the sea from oil spills and also naturally produced by some marine plankton such as Bacillariophyceae, Cryptophyceae, Haptophyceae, and Euglenophyceae (Rontani and Bonin, 2011). Cui et al., (2020) reported Bacterium, Burkholderia-Paraburkholderia, Luteibacter, and Acinetobacter mainly contributed to petroleum hydrocarbons degradation under optimal condition.

\section{Factors influencing petroleum hydrocarbon degradation}

Several limiting factors have been reported to affect the biodegradation of petroleum hydrocarbons. The interaction among 
community members and the environment such as competition for limiting nutrients, predation by protozoa, lysis by phage, and cooperative interactions could increase degradation as shown in fig.1 (Head et al., 2006).

\section{Temperature}

Temperature affects both the physical state of hydrocarbons and microbes residing on them (Leahy and Colwell, 1990; Chandra et al., 2013). It also affects microbial growth rate, gas solubilities, soil matrix, metabolism in microbes, physical and chemical state of contaminants (Megharaj et al., 2011). It was reported that an increase in temperature increases solubility of hydrophobic pollutants, decrease viscosity, enhances diffusion, and transfer long-chain n-alkanes from solid phase to water phase (Aislabie et al., 2006). The viscosity of oil increases, volatilization of toxic short-chain alkanes is reduced and their water solubility is decreased which delay the onset of biodegradation at low temperature (Leahy and Colwell, 1990). Cui et al., (2020) showed the degradation rates of petroleum hydrocarbons were gradually increased with increasing temperature to optimal condition.

\section{Salinity and pressure}

Salinity also hampers microbial growth and their products (Leahy and Colwell, 1990). Atlas (1981), has reported that salinity and pressure are specific features of typical ecosystems such as saline lakes or deep seas, which represent a particular environment that may be polluted by petroleum hydrocarbons. Minai-Tehrani et al., (2006), have noted $41 \%$ crude oil degradation for 4 months incubation in soil samples without $\mathrm{NaCl}$ addition, while $12 \%$ crude oil degradation for 4 months incubation was obtained in same soil samples when $50 \mathrm{~g} / \mathrm{L} \mathrm{NaCl}$ was added. Experiments for biodegradation of hexadecane, tetradecane, and mixed hydrocarbon substrate using a mixed culture of deep-sea sediment bacteria were performed at high pressure of $495 \mathrm{~atm}$ or $500 \mathrm{~atm}$ and atmospheric temperature of $1 \mathrm{~atm}$ (Schwarz et al., 1975). They have concluded that hydrocarbon pollutants when reaching the deep ocean environment, some petroleum components may pollute deep benthic zones of the oceans. Varjaniand Upasani (2017) suggest that these pollutants in benthic zones of oceans are biodegraded very slowly due to the recalcitrant fraction of petroleum oil that could persist for a long time may be years or decades.

\section{Substrate and properties}

Petroleum hydrocarbon mineralization is affected by its concentration (Leahy and Colwell, 1990). With increased petroleum oil concentration lags phase decreases, whereas maximum degrading rates and cumulative extents of mineralization increases (Towell et al., 2011). Petroleum hydrocarbon degradability also depends on its composition (Atlas, 1981). Biodegradability of hydrocarbons can be ranked in decreasing order as: linear alkanes > branched alkanes > low-molecular-weight alkyl aromatics > monoaromatics > cyclic alkanes > polyaromatics > asphaltenes (Varjani, 2017). Immensely high complete oil hydrocarbon fixations have affirmed deadly to microbial action consequently restricting biodegradation potential (Admon et al., 2001). Tremendously low total petroleum hydrocarbon concentrations can limit biodegradation as carbon supply may be too low that supports the growth of microbes (Leahy and Colwell, 1990). Typically, the biodegradation rate increases with decreasing molecular weight and chemical structure complexity of hydrocarbon (Varjani, 2017). The same compound(s) in different petroleum crude is degraded to different extents by the same or 
other organisms/consortium, the reason could be bioavailability of that compound(s) (Varjani, 2017). Physicochemical properties of crude oil and polluted sites are essential for a successful bioremediation process (Varjani et al., 2014b). These factors have a direct influence on the type, number, and metabolic activities of the microflora of any ecosystem (Admon et al., 2001; Ghazali et al., 2004). Hydrocarbon degraders prefer the utilization of less complex compounds (Atlas, 1998). Biodegradability is inherently influenced by the composition of pollutants (Ruberto et al., 2003). Crude oil having major constituent as saturates and/or aromatics is biodegradable, however, for heavy asphaltic-naphthenic crude oils, approximately $11 \%$ may be biodegradable within a reasonable period under favorable growth conditions for microorganisms (Ghazali et al., 2004).

\section{Availability of nutrients}

The availability of nutrients plays an important role in microbial activities (Varjani and Upasani, 2017). The type and concentration of carbon and nitrogen source used in culture medium play a vital role for microbial growth (Atlas, 1981; Jagadevan and Mukherji, 2004; Zhao et al., 2011). Microorganisms require nitrogen and phosphorus for incorporation into biomass, the availability of these nutrients within the same area as hydrocarbons is critical (Atlas, 1981). Like biological oxygen demand, nitrogen demand is important for the biodegradation of hydrocarbons (Atlas, 1981). Varjani (2017), has reviewed that petroleum hydrocarbons do not contain a significant amount of some nutrients viz. such as nitrogen and phosphorous required for microbial growth. However, urea, phosphate, N-P-K fertilizers, ammonium, and phosphate salts can be used to adjust carbon/nitrogen/phosphorous/potassium (C$\mathrm{N}-\mathrm{P}-\mathrm{K}$ ) ratios. Generally, $\mathrm{C}: \mathrm{N}: \mathrm{P}$ to promote microbial growth is 100:10:1 (Varjani and Upasani, 2017). Atlas (1995) has reported that the addition of nitrogenous fertilizers shows increased rates of petroleum hydrocarbon biodegradation. In contrast, Varjani et al., (2014a) described that no significant effect in petroleum hydrocarbon biodegradation was observed on nitrogen source addition.

Toda and Itoh (2012) reported that nitrate as the best source of nitrogen for growth and biosurfactant production by microorganisms. Walworth et al., (2005), reported that treating petroleum polluted site with nitrogen increases cell growth rate as well as hydrocarbon degradation rate by decreasing the lag phase of microbial growth and maintaining microbial populations at high activity levels. However, it has been shown that excessive amounts of nitrogen in soil cause microbial inhibition. Maintaining nitrogen levels below $1800 \mathrm{mg}$ nitrogen $/ \mathrm{kg}$ $\mathrm{H}_{2} \mathrm{O}$ leads to optimal biodegradation of hydrocarbon pollutants (Walworth et al., 2007). Excessive nutrient concentrations especially high concentrations of NPK levels inhibit biodegradation activity of hydrocarbon pollutants (Boopathy, 2000; Souza et al., 2014). In addition to this high concentration of these pollutants in polluted sites disturb $\mathrm{C}$ : $\mathrm{N}$ : $\mathrm{P}$ ratio which leads to oxygen limitations (Varjani and Upasani, 2017).

\section{Biosurfactant and bioavailability of pollutants}

The bioavailability of petroleum crude pollutants to microbes plays a key role in the bioremediation process (Saeki et al., 2009; Souza et al., 2014). Hydrocarbon pollutants transport to microbial cells through (a) interaction of microbial cells to hydrocarbon pollutants dissolved in an aqueous phase, (b) direct contact of cells with hydrocarbons, and (c) interaction of cells with hydrocarbon droplets much smaller than cells (Goswami 
and Singh, 1991; Kavitha et al., 2014). Pollutant bioavailability depends on its chemical properties viz. hydrophobicity and volatility; soil properties; environmental conditions and biological activity (PilonSmits, 2005; Yalcin et al., 2011; Varjani et al., 2014a). However, solubility and dissolution rates play a critical role in bioavailability (Kavitha et al., 2014). Hydrophobic, less water-soluble molecules sorb more strongly to soil components than hydrophilic molecules (Jain et al., 2011). Microbial products such as acids, biosurfactants/bioemulsifiers, solvents, gases, and biopolymers also enhance bioremediation and oil recovery (Brito et al., 2006; Yalcin et al., 2011; Varjani and Upasani, 2016; Zhao et al., 2016). Biosurfactants are secondary metabolites and produced in the stationary phase of microbial growth (Banat et al., 2010).

Biosurfactants are amphiphilic molecules that may stimulate dissolution or desorption rates, solubilization, or even emulsification of hydrocarbon pollutants (Dias et al., 2012; Kavitha et al., 2014). It is interestingly showing about the application of microbial surfactant over chemical surfactants due to (a) ability to be synthesized from renewable feed stocks (Yan et al., 2012; Zhao et al., 2016) (b) relative nontoxicity and higher biodegradability (Souza et al., 2014; Varjani and Upasani, 2016a), (c) unique structural properties for application in environmental clean-up (Souza et al., 2014; Zhao et al., 2016) and (d) higher foaming capacity, high selectivity and specific activity at harsh environmental conditions viz. temperature, $\mathrm{pH}$ and salinity (Varjani and Upasani, 2016). Surface active agents at low concentrations bring about changes in interfacial tension (Rabiei et al., 2013). But, at increased concentration, a critical concentration reaches beyond which no change in interfacial properties is observed (Desai and Banat,
1997; Souza et al., 2014). Beyond this critical concentration, surfactant molecules form micelles (Desai and Banat, 1997). Micelle formation enables surfactant to reduce surface and interfacial tension which sequentially results in increased solubility and bioavailability of hydrophobic compounds (Rabiei et al., 2013; Souza et al., 2014). By reducing surface tension and interfacial tension biosurfactant reduces repulsive forces between two dissimilar phases and helps these two phases to mix and interact more easily (Desai and Banat, 1997; Mulligan, 2005; Souza et al., 2014). Several bacterial sp. can grow exclusively on hydrocarbons and produce biosurfactants (Mulligan, 2005). Petroleum-degrading and biosurfactant producing microorganisms are widely distributed in soil, water, and sediments (Yakimov et al., 2007). Many microorganisms isolated from oil reservoirs can produce biosurfactants (Waigi et al., 2015) which are of interest in bioremediation of petroleum hydrocarbon polluted sites and microbial enhanced oil recovery (MEOR).

\section{Mechanism of petroleum hydrocarbon degradation}

The rapid and complete degradation of most organic pollutants occurs under aerobic conditions. The foremost intra-cellular organic pollutant attack takes the form of oxidation and activation, and also the integration of oxygen is the key enzymatic catalyst via peroxidases and oxygenates. Das and Chandran, (2011) explained the pathways of peripheral degradation transform organic pollutants stepwise in intermediates of the central intermediary metabolism, viz. the tricarboxylicacid cycle. The cell biomass biosynthesis happens from the metabolites of the central precursors, for instance, the acetylCoA, pyruvate, and succinate (Das and Chandran, 2011; Al-Hawash et al., 2018). 
The saccharides necessary for different biosynthesis and growth are synthesized via gluconeogenesis. Petroleum hydrocarbon degradation could be possible either a) via a specific enzyme system, b) microbial cell attachment to substrates and c) biosurfactant production (Rahman et al., 2003). Petroleum hydrocarbons can be selectively metabolized from an individual strain of microorganism or a microbial consortium of strains relevant to the irrespective genera (Varjani and Upasani, 2016). The consortium had shown to be more possible than the individual cultures to metabolizing or degrading of petroleum hydrocarbons (Al-Hawash et al., 2018).Most recently, the degradation process of diesel by $\mathrm{HDMP}_{2}$ could be divided into three stages such as surface adsorption, cell uptake, and biodegradation. At the initial stage, the diesel components were quickly adsorbed on the surface of $\mathrm{HDMP}_{2}$. Then, except for little into a cell, the most diesel components were continuously gathered and finally degraded into $\mathrm{CnHn}, \mathrm{CO}_{2}$, and $\mathrm{H}_{2} \mathrm{O}$ (Yang et al., 2020).

\section{Enzymes participating in the degradation of hydrocarbons}

Cytochrome P450 alkane hydroxylases isolated from Candida species, including Candida apicola, C. maltose and C. tropicalis (Scheller et al., 1998) comprise a supergroup of omnipresent Heme-thiolate Monooxygenases which assume a significant job in the microbial corruption of oil, chlorinated hydrocarbons, fuel added substances, and numerous different mixes (Van Beilen and Funhoff, 2007).Depending on the chain length, enzyme systems are required to acquaint oxygen in the substrate to initiate biodegradation (Table 2). Higher eukaryotes generally contain several different P450 families that comprise a large number of individual P450 forms that may pay as a group of isoforms to the metabolic conversion of a given substrate. Cytochrome P450 enzyme systems were engaged in biodegradation of petroleum hydrocarbons. The ability of various yeast species to utilize n-alkanes and other aliphatic hydrocarbons as a sole wellspring of carbon and energy is mediated by the presence of numerous microsomal Cytochrome P450 forms. The assorted variety of alkane oxygenase systems in eukaryotes and prokaryotes that are vigorously taking an interest in the debasement of alkanes under aerobic conditions like Cytochrome P450 enzyme, soluble di-iron methane monooxygenases, integral membrane di-iron alkane hydroxylases (e.g., alkB) and membranebound copper-containing methane monooxygenases, lipase, esterase (Das and Chandran, 2011; Kadri et al., 2018).

Fig-1 shows the interaction among bacterial community members and the environment. This outline demonstrates that oil biodegradation includes progressively natural parts rather than the microorganisms that legitimately assault oil (the essential oil degraders) and shows that the essential oil degraders communicate with these segments. It is indicated that oil-degrading bacteria as a red color, solid arrow as material influxes, broken arrows as direct interactions viz. lysis by phage and predation by protozoa. For simplicity, only one function is assigned to a microorganism in this representation. However, it should be noted that a microorganism can have more than one function or ability, for instance, to weather minerals to release phosphate $(\mathrm{P})$, and to degrade the oil. It should also be well-known that primary oil degraders need to compete with other microorganisms for limiting nutrients such as $\mathrm{P}$ and those non-oildegrading microorganisms which are shown as a brown color that can be affected by metabolites and other compounds that are released by oil-degrading bacteria and vice versa (Head et al., 2006). 
Table.1 Petroleum hydrocarbon-degrading microbes and their preferred degradation substrates

\begin{tabular}{|c|c|c|c|}
\hline $\begin{array}{l}\text { Petroleum } \\
\text { hydrocarbon } \\
\text { components }\end{array}$ & Bacterial species & $\begin{array}{l}\text { Main degrading } \\
\text { compound }\end{array}$ & Reference \\
\hline \multirow{7}{*}{$\begin{array}{l}\text { aromatic } \\
\text { hydrocarbons }\end{array}$} & Neptunomonas naphthovoran & Polyaromatics & Hedlund et al., 1999 \\
\hline & Cycloclasticus & & Kasai et al., 2002 \\
\hline & Pseudomonas aeruginosa & Monoaromatics & Mukherjee et al., 2010 \\
\hline & Mycobacterium cosmeticum & Monoaromatics & Zhang et al., 2013 \\
\hline & Aeribacillus pallidus & Mono-/polyaromatics & Mnif et al., 2014 \\
\hline & Achromobacter xylosoxidans & Mono-/polyaromatics & Ma et al., 2015 \\
\hline & $\begin{array}{l}\text { Bacillus licheniformis } \\
\text { Bacillus mojavensis }\end{array}$ & Polyaromatics & $\begin{array}{l}\text { Eskandari et al., } \\
2017\end{array}$ \\
\hline \multirow{8}{*}{$\begin{array}{l}\text { Saturated } \\
\text { hydrocarbons }\end{array}$} & Pseudomonas sp. & n-alkanes (C14-C30) & Sugiura et al., 1997 \\
\hline & Alcanivora $x \mathrm{sp}$ & $\begin{array}{l}\mathrm{n} \text {-alkanes and } \\
\text { branched alkanes }\end{array}$ & Hara et al., 2003 \\
\hline & Oleispira antarctica & n-alkanes (C10-C18) & Yakimov et al., 2003 \\
\hline & Rhodococcus ruber & n-alkanes (C13-C17) & Zhukov et al., 2007 \\
\hline & Rhodococcus sp. & Cyclohexane & Lee and Cho, 2008 \\
\hline & Dietzia sp. & n- alkanes (C6-C40) & Wang et al., 2011 \\
\hline & Geobacillus thermodenitrifican & n-alkanes (C15-C36) & Abbasian et al., 2015 \\
\hline & Gordonia sihwensis & $\begin{array}{l}\text { Branched and normal } \\
\text { alkanes }\end{array}$ & Brown et al., 2016 \\
\hline Resins & Pseudomonas sp. & Resins & Venkateswaran et al., 1995 \\
\hline \multirow[t]{2}{*}{ Asphaltenes } & $\begin{array}{l}\text { Seudomonas spp., } \\
\text { Bacillus sp. }\end{array}$ & Asphaltenes & Tavassoli et al., 2012 \\
\hline & $\begin{array}{l}\text { Citrobacter } \mathrm{sp} ., \text { Enterobacter } \\
\mathrm{sp} ., \text { Staphylococcus } \mathrm{sp} ., \\
\text { Lysinibacillus sp. Bacillus sp., } \\
\text { Pseudomonas sp. }\end{array}$ & Asphaltenes & Jahromi et al., 2014 \\
\hline
\end{tabular}

Table.2 Enzymes involved in the degradation of hydrocarbons

\begin{tabular}{|l|l|l|l|}
\hline Enzymes & Substrate & Microorganism & Reference \\
\hline $\begin{array}{l}\text { Alkane hydroxylase, lipase, } \\
\text { and esterase }\end{array}$ & $\begin{array}{l}\text { hexane, } \\
\text { hexadecane and } \\
\text { motor oil }\end{array}$ & $\begin{array}{l}\text { Alcanivorax } \\
\text { borkumensis }\end{array}$ & $\begin{array}{l}\text { T. Kadri } \text { et al., } \\
2018\end{array}$ \\
\hline Eukaryotic P450 & $\begin{array}{l}\text { C10-C16 } \\
\text { alkanes, fatty } \\
\text { acids }\end{array}$ & $\begin{array}{l}\text { Candida maltose, } \\
\text { Candida tropicalis, } \\
\text { Yarrowialipolytica }\end{array}$ & Iida et al., 2000 \\
\hline $\begin{array}{l}\text { AlkB-related alkane } \\
\text { hydroxylases }\end{array}$ & $\begin{array}{l}\text { C5-C16 } \\
\text { alkanes, fatty } \\
\text { acids, } \\
\text { alkylbenzenes, } \\
\text { cycloalkanes, } \\
\text { etc. }\end{array}$ & $\begin{array}{l}\text { Acinetobacter, } \\
\text { Alcanivorax, } \\
\text { Burkholderia, } \\
\text { Mycobacterium, } \\
\text { Pseudomonas, } \\
\text { Rhodococcus, etc. }\end{array}$ & $\begin{array}{l}\text { van Beilen } \\
\text { et al., } \\
(2003)\end{array}$ \\
\hline
\end{tabular}




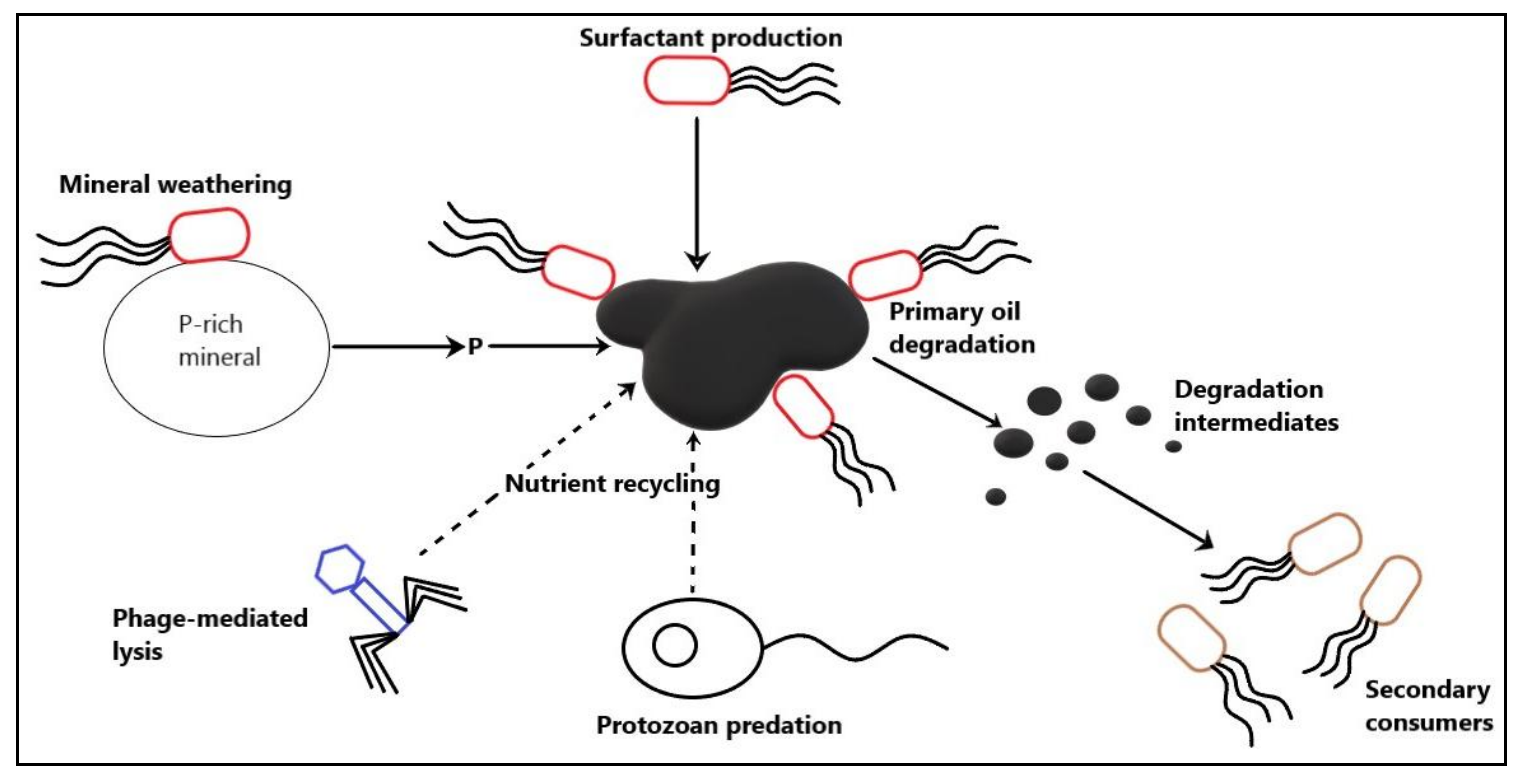

Fig.1 The interaction among bacterial community members and the environment

It is concluded as petroleum hydrocarbon pollutant in the marine environment is one of the major concern to be addressed to mitigate by using any possible ways. Biodegradation of persistent organic pollutants can be performed using oleophilic microorganisms either as an individual organism or consortium of microorganisms to control environmental pollution. Understanding factors affecting biodegradation is of great research interest. Additional studies could be carried out to compare the performance or efficiency of isolated strains.

\section{References}

Abbriano, R. M., CARRANzA, M. M., Hogle, S. L., Levin, R. A., Netburn, A. N., Seto, K. L., Snyder, S.M. and Franks, P. J., 2011. Deepwater Horizon oil spill: A review of the planktonic response. Oceanography, 24(3): 294301.

Admon, S., Green, M. and Avnimelech, Y., 2001. Biodegradation kinetics of hydrocarbons in soil during land treatment of oily sludge. Bioremediation Journal, 5(3): 193-209.
Alhujaily, A., Abbood, H.A., Zhang, X. and Ma, F., 2018. Principles of microbial degradation of petroleum hydrocarbons in the environment. The Egyptian Journal of Aquatic Research, 44(2): 71-76.

Aislabie, J., Saul, D.J. and Foght, J.M., 2006. Bioremediation of hydrocarboncontaminated polar soils. Extremophiles, 10(3): 71-179.

Atlas, R.M., 1981. Microbial degradation of petroleum hydrocarbons: an environmental perspective. Microbiological Reviews, 45(1): 180209.

Atlas, R.M. (1984). Diversity of microbial communities. In Advances in Microbial Ecology, pp.1-47.

Atlas, R. M., 1995. Petroleum biodegradation and oil spill bioremediation. Marine pollution bulletin, 31(4-12): 178-182.

Atlas, R. M., 1998. Microbial ecology: fundamentals and applications. Pearson Education India.

Atlas, R.M. and Bartha, R., 1992. Hydrocarbon biodegradation and oil spill bioremediation. In Advances in Microbial Ecology, pp. 287-338.

Banat, I.M., 1995. Biosurfactants production 
and possible uses in microbial enhanced oil recovery and oil pollution remediation: a review. Bioresource Technology, 51(1): 1-12.

Brown, L. M., Gunasekera, T. S., Striebich, R. C., and Ruiz, O. N., 2016. Draft genome sequence of Gordoniasihwensis strain 9, a branched alkane-degrading bacterium. Genome Announc., 4(3): e00622-16.

Brito, E.M.S., Guyoneaud, R., Goñi-Urriza, M., Ranchou-Peyruse, A., Verbaere, A., Crapez, M.A., Wasserman, J.C.A. and Duran, R., 2006. Characterization of hydrocarbonoclastic bacterial communities from mangrove sediments in Guanabara Bay, Brazil. Research in Microbiology, 157(8):752-762.

Bragg, J.R. and Owens, E.H., 1994. Clay-oil flocculation as a natural cleansing process following oil spills: Part 1 . Studies of shoreline sediments and residues from past spills. ENVIRONMENT CANADA, OTTAWA, ON(CANADA)., 1: 1-23.

Banat, I.M., Franzetti, A., Gandolfi, I., Bestetti, G., Martinotti, M.G., Fracchia, L., Smyth, T.J. and Marchant, R., 2010. Microbial biosurfactants production, applications and future potential. Applied Microbiology and Biotechnology, 87(2): 427-444.

Boopathy, R., 2000. Factors limiting bioremediation technologies. Bioresource Technology, 74(1): 63-67.

Chandra, S., Sharma, R., Singh, K. and Sharma, A., 2013. Application of bioremediation technology in the environment contaminated with petroleum hydrocarbon. Annals of Microbiology, 63(2): 417-431.

Cui, J., Chen, H., Sun, M. and Wen, J., 2020. Comparison of bacterial community structure and function under different petroleum hydrocarbon degradation conditions. Bioprocess and Biosystems
Engineering, 43(2): 303-313.

Desai, J.D. and Banat, I.M., 1997. Microbial production of surfactants and their commercial potential. Microbiology and Molecular Biology Reviews, 61(1): 4764.

Das, N. and Chandran, P., 2011. Microbial degradation of petroleum hydrocarbon contaminants: an overview. Biotechnology research international, 2011: 1-13.

Dias, R. L., Ruberto, L., Hernández, E., Vázquez, S. C., Balbo, A. L., Del Panno, M. T., and Mac Cormack, W. P., 2012. Bioremediation of an aged diesel oil-contaminated Antarctic soil: Evaluation of the "on site" biostimulation strategy using different nutrient sources. International biodeterioration and biodegradation, 75: 96-103.

Eskandari, S., Hoodaji, M., Tahmourespour, A., Abdollahi, A., MohammadianBaghi, T., Eslamian, S., \&Ostad-AliAskari, K., 2017. Bioremediation of polycyclic aromatic hydrocarbons by Bacillus Licheniformis ATHE9 and Bacillus Mojavensis ATHE13 as newly strains isolated from oil-contaminated soil. Journal of Geography, Environment and Earth Science International, 11(2): 1-11.

Ghazali, F.M., Rahman, R.N.Z.A., Salleh, A.B. and Basri, M., 2004. Biodegradation of hydrocarbons in soil by microbial consortium. International Biodeterioration and Biodegradation, 54(1): 61-67.

Ghosal, D., Ghosh, S., Dutta, T. K., \&Ahn, Y. 2016. Corrigendum: Current State of Knowledge in Microbial Degradation of Polycyclic Aromatic Hydrocarbons (PAHs): A Review. Frontiers in microbiology, 7: 1837.

Gong, H., Li, Y., Bao, M., Lv, D. and Wang, Z., 2015. Petroleum hydrocarbon 
degrading bacteria associated with chitosan as effective particle-stabilizers for oil emulsification. Rsc Advances, 5(47): 37640-37647.

Goswami, P. and Singh, H.D., 1991. Different modes of hydrocarbon uptake by two Pseudomonas species. Biotechnology and Bioengineering, 37(1): 1-11.

Head, I.M., Jones, D.M. and Röling, W.F., 2006. Marine microorganisms make a meal of oil. Nature Reviews Microbiology, 4(3): 173-182.

Hara, A., Syutsubo, K., and Harayama, S., 2003. Alcanivorax which prevails in oil- contaminated seawater exhibits broad substrate specificity for alkane degradation.

Environmental Microbiology, 5(9): 746-753.

Hedlund, B. P., Geiselbrecht, A. D., Bair, T. J., and Staley, J. T., 1999. Polycyclic aromatic hydrocarbon degradation by a new marine bacterium, Neptunomonas naphthovorans gen. nov., sp. nov. Applied and Environmental Microbiology, 65(1): 251-259.

Hommel, R.K., 1997. Formation and physiological role of biosurfactants produced by hydrocarbon-utilizing microorganisms. Physiology of Biodegradative Microorganisms, pp. 107-119

Iida, T., Sumita, T., Ohta, A., and Takagi, M., 2000. The cytochrome P450ALK multigene family of an n- alkane- assimilating yeast, Yarrowiali polytica: cloning and characterization of genes coding for new CYP52 family members. Yeast, 16(12): 1077-1087.

Jagadevan, S. and Mukherji, S., 2004. Successful in situ oil bioremediation programmes-Key parameters. Indian Journal of Biotechnology, 3: 495-501.

Jahromi, H., Fazaelipoor, M. H., Ayatollahi, S., and Niazi, A., 2014. Asphaltenes biodegradation under shaking and static conditions. Fuel, 117: 230-235.

Jain, P.K., Gupta, V.K., Gaur, R.K., Lowry, M., Jaroli, D.P. and Chauhan, U.K., 2011. Bioremediation of petroleum oil contaminated soil and water. Research Journal of Environmental Toxicology, 5(1): 1-26.

Joshi, B. and Walia, S., 1996. PCR amplification of catechol 2, 3dioxygenase gene sequences from naturally occurring hydrocarbon degrading bacteria isolated from petroleum hydrocarbon contaminated groundwater. FEMS Microbiology Ecology, 19(1): 5-15.

Kadri, T., Rouissi, T., Magdouli, S., Brar, S.K., Hegde, K., Khiari, Z., Daghrir, R. and Lauzon, J.M., 2018. Production and characterization of novel hydrocarbon degrading enzymes from Alcanivorax borkumensis. International Journal of Biological Macromolecules, 112: 230240.

Kasai, Y., Kishira, H., and Harayama, S., 2002. Bacteria belonging to the genus Cycloclasticus play a primary role in the degradation of aromatic hydrocarbons released in a marine environment. Applied and Environmental Microbiology, 68(11): 5625-5633.

Kavitha, V., Mandal, A.B. and Gnanamani, A., 2014. Microbial biosurfactant mediated removal and/or solubilization of crude oil contamination from soil and aqueous phase: an approach with Bacillus licheniformis MTCC 5514. International Biodeterioration and Biodegradation, 94: 24-30.

Kraiselburd, I., Brüls, T., Heilmann, G., Kaschani, F., Kaiser, M. and Meckenstock, R.U., 2019. Metabolic reconstruction of the genome of candidate Desulfatiglans TRIP_1 and identification of key candidate enzymes for anaerobic phenanthrene degradation. Environmental Microbiology, 21(4): 
1267-1286.

Lee, E. H., and Cho, K. S., 2008. Characterization of cyclohexane and hexane degradation by Rhodococcus sp. EC1. Chemosphere, 71(9): 1738-1744.

Leahy, J.G. and Colwell, R.R., 1990. Microbial degradation of hydrocarbons in the environment. Microbiology and Molecular Biology Reviews, 54(3): 305315.

Ma, Y. L., Lu, W., Wan, L. L., and Luo, N., 2015. Elucidation of fluoranthene degradative characteristics in a newly isolated Achromobacter xylosoxidans DN002. Applied Biochemistry and Biotechnology, 175(3): 1294-1305.

Megharaj, M., Ramakrishnan, B., Venkateswarlu, K., Sethunathan, N. and Naidu, R., 2011. Bioremediation approaches for organic pollutants: a critical perspective. Environment international, 37(8): 1362-1375.

Minai-Tehrani, D., Herfatmanesh, A., AzariDehkordi, F. and Minuoi, S., 2006. Effect of salinity on biodegradation of aliphatic fractions of crude oil in soil. Pakistan Journal of Biological Sciences, 9(8): 1531-5.

Mnif, S., Sayadi, S., \&Chamkha, M., 2014. Biodegradative potential and characterization of a novel aromaticdegrading bacterium isolated from a geothermal oil field under saline and thermophilic conditions. International Biodeterioration and Biodegradation, 86: 258-264.

Mulligan, C.N., 2005. Environmental applications for biosurfactants. Environmental Pollution, 133(2): 183198.

Mukherjee, S., Bardolui, N. K., Karim, S., Patnaik, V. V., Nandy, R. K., and Bag, P. K., 2010. Isolation and characterization of a monoaromatic hydrocarbon-degrading bacterium, Pseudomonas aeruginosa from crude oil. Journal of Environmental Science and Health Part A, 45(9): 1048-1053.

Okpokwasili, G.C. and Amanchukwu, S.C., 1988. Petroleum hydrocarbon degradation by Candida species. Environment International, 14(3): 243247.

Pilon-Smits, E., 2005. Phytoremediation. Annual Review of Plant Biology, 56: 1539.

Rabiei, A., Sharifinik, M., Niazi, A., Hashemi, A. and Ayatollahi, S., 2013. Core flooding tests to investigate the effects of IFT reduction and wettability alteration on oil recovery during MEOR process in an Iranian oil reservoir. Applied microbiology and biotechnology, 97(13): 5979-5991.

Rahman, K.S., Rahman, T.J., Kourkoutas, Y., Petsas, I., Marchant, R. and Banat, I.M., 2003. Enhanced bioremediation of nalkane in petroleum sludge using bacterial consortium amended with rhamnolipid and micronutrients. Bioresource technology, 90(2): 159168.

Rontani, J.F. and Bonin, P., 2011. Production of pristane and phytane in the marine environment: role of prokaryotes. Research in microbiology, 162(9): 923933.

Ruberto, L., Vazquez, S.C. and Mac Cormack, W.P., 2003. Effectiveness of the natural bacterial flora, biostimulation and bioaugmentation on the bioremediation of a hydrocarbon contaminated Antarctic soil. International Biodeterioration and Biodegradation, 52(2): 115-125.

Saeki, H., Sasaki, M., Komatsu, K., Miura, A. and Matsuda, H., 2009. Oil spill remediation by using the remediation agent JE1058BS that contains a biosurfactant produced by Gordonia sp. strain JE-1058. Bioresource Technology, 100(2): 572-577. 
Scheller, U., Zimmer, T., Becher, D., Schauer, F. and Schunck, W.H., 1998. Oxygenation cascade in conversion of n-alkanes to $\alpha, \omega$-dioic acids catalyzed by cytochrome P450 52A3. Journal of Biological Chemistry, 273(49): 3252832534.

Schwarz, J.R., Walker, J.D. and Colwell, R.R., 1975. Deep-sea bacteria: growth and utilization of n-hexadecane at in situ temperature and pressure. Canadian Journal of Microbiology, 21(5): 682687.

Souza, E.C., Vessoni-Penna, T.C. and de Souza Oliveira, R.P., 2014. Biosurfactant-enhanced hydrocarbon bioremediation: An overview. International biodeterioration and biodegradation, 89: 88-94.

Sugiura, K., Ishihara, M., Shimauchi, T., and Harayama, S., 1996. Physicochemical properties and biodegradability of crude oil. Environmental Science and Technology, 31(1): 45-51.

Tao, X., 2019. Identification of Petroleum Degrading Bacteria and Construction of Petroleum Degrading Agent. Open Access Library Journal, 6(04): 1-10.

Tavassoli, T., Mousavi, S. M., Shojaosadati, S. A., and Salehizadeh, H., 2012. Asphaltene biodegradation using microorganisms isolated from oil samples. Fuel, 93: 142-148.

Toda, H., and Itoh, N., 2012. Isolation and characterization of styrene metabolism genes from styrene-assimilating soil bacteria Rhodococcus sp. ST-5 and ST10. Journal of Bioscience and Bioengineering, 113(1): 12-19.

Tong, K., Zhang, Y., Liu, G., Ye, Z. and Chu, P.K., 2013. Treatment of heavy oil wastewater by a conventional activated sludge process coupled with an immobilized biological filter. International Biodeterioration and Biodegradation, 84: 65-71.
Towell, M.G., Paton, G.I. and Semple, K.T., 2011. The biodegradation of cable oil components: Impact of oil concentration, nutrient addition and bioaugmentation. Environmental pollution, 159(12):3777-3783.

Van Beilen, J. B., Li, Z., Duetz, W. A., Smits, T. H. M., and Witholt, B., 2003. Diversity of alkane hydroxylase systems in the environment. Oil \&Gas Science and Technology, 58(4): 427-440.

Van Beilen, J.B. and Funhoff, E.G., 2005. Expanding the alkane oxygenase toolbox: new enzymes and applications. Current Opinion in Biotechnology, 16(3): 308-314.

Van Beilen, J.B. and Funhoff, E.G., 2007. Alkane hydroxylases involved in microbial alkane degradation. Applied microbiology and biotechnology, 74(1): 13-21.

Varjani, S.J., 2014. Hydrocarbon degrading and biosurfactants (bio-emulsifiers) producing bacteria from petroleum oil wells (Doctoral dissertation, PhD thesis, Kadi Sarva Vishwavidyalaya, Gandhinagar, India).

Varjani, S., THAKER, M. and Upasani, V., 2014. Optimization of growth conditions of native hydrocarbon utilizing bacterial consortium "HUBC" obtained from petroleum pollutant contaminated sites. Indian Journal of Applied Research, 4(10): 474-476.

Varjani, S.J., Rana, D.P., Bateja, S., Sharma, M.C. and Upasani, V.N., 2014. Screening and identification of biosurfactant (bioemulsifier) producing bacteria from crude oil contaminated sites of Gujarat, India. International Journal of Innovative Research in Science, Engineering and Technology. 3(2): 9205-9213.

Varjani, S.J. and Upasani, V.N., 2016. Carbon spectrum utilization by an indigenous strain of Pseudomonas aeruginosa 
NCIM 5514: Production, characterization and surface active properties of biosurfactant. Bioresource Technology, 221: 510-516.

Varjani, S.J., 2017. Microbial degradation of petroleum hydrocarbons. Bioresource Technology, 223: 277-286.

Varjani, S.J. and Upasani, V.N., 2017. A new look on factors affecting microbial degradation of petroleum hydrocarbon pollutants. International

Biodeterioration and Biodegradation, 120: 71-83.

Venkateswaran, K., Hoaki, T., Kato, M., and Maruyama, T., 1995. Microbial degradation of resins fractionated from Arabian light crude oil. Canadian Journal of Microbiology, 41(4-5): 418424.

Wang, X. B., Chi, C. Q., Nie, Y., Tang, Y. Q., Tan, Y., Wu, G., and Wu, X. L., 2011. Degradation of petroleum hydrocarbons (C6-C40) and crude oil by a novel Dietzia strain. Bioresource Technology, 102(17): 7755-7761.

Waigi, M.G., Kang, F., Goikavi, C., Ling, W. and Gao, Y., 2015. Phenanthrene biodegradation by sphingomonads and its application in the contaminated soils and sediments: a review. International Biodeterioration and Biodegradation, 104: 333-349.

Walworth, J., Pond, A., Snape, I., Rayner, J., Ferguson, S. and Harvey, P., 2005. Fine tuning soil nitrogen to maximize petroleum bioremediation. Assessment and remediation contaminated sites in Arctic and cold climates (ARCSACC), 251:251-255.

Walworth, J., Pond, A., Snape, I., Rayner, J., Ferguson, S., and Harvey, P., 2007. Nitrogen requirements for maximizing petroleum bioremediation in a subAntarctic soil. Cold Regions Science and Technology, 48(2): 84-91.

Xu, X., Liu, W., Tian, S., Wang, W., Qi, Q.,
Jiang, P., Gao, X., Li, F., Li, H. and Yu, H., 2018. Petroleum hydrocarbondegrading bacteria for the remediation of oil pollution under aerobic conditions: a perspective analysis. Frontiers in Microbiology, 9:1-11.

Yakimov, M.M., Giuliano, L., Gentile, G., Crisafi, E., Chernikova, T.N., Abraham, W.R., Lünsdorf, H., Timmis, K.N. and Golyshin, $\quad$ P.N., 2003. Oleispiraantarctica gen. nov., sp. nov., a novel hydrocarbonoclastic marine bacterium isolated from Antarctic coastal sea water. International Journal of Systematic and Evolutionary Microbiology, 53(3): 779-785.

Yakimov, M.M., Timmis, K.N. and Golyshin, P.N. (2007). Obligate oil-degrading marine bacteria. Current Opinion in Biotechnology, 18(3): 257-266.

Yalçin, E., Çavuşoğlu, K. and Özen, E., 2011. Hydrocarbon degradation by a new Pseudomonas sp., strain RW-II, with polycationic surfactant to modify the cell hydrophobicity. Environmental technology, 32(15): 1743-1747.

Yan, P., Lu, M., Yang, Q., Zhang, H.L., Zhang, Z.Z. and Chen, R., 2012. Oil recovery from refinery oily sludge using a rhamnolipid biosurfactant-producing Pseudomonas. Bioresource technology, 116: 24-28.

Yang, Y., Liu, Y., Li, N., Shi, K., Xue, J., Gao, Y. and Xiao, X., 2020. Isolation, enhanced growth, and degradation characterization of a strain marine petroleum degrading bacteria. Environmental Technology and Innovation, pp.100796.

Zhang, L., Zhang, C., Cheng, Z., Yao, Y., and Chen, J., 2013. Biodegradation of benzene, toluene, ethylbenzene, and oxylene by the bacterium Mycobacterium cosmeticum byf-4. Chemosphere, 90(4): 1340-1347.

Zhao, F., Zhou, J.D., Ma, F., Shi, R.J., Han, 
S.Q., Zhang, J. and Zhang, Y., 2016. Simultaneous inhibition of sulfatereducing bacteria, removal of $\mathrm{H} 2 \mathrm{~S}$ and production of rhamnolipid by recombinant Pseudomonas stutzeriRhl: applications for microbial enhanced oil recovery. Bioresource Technology, 207: 24-30.
Zhukov, D. V., Murygina, V. P., \&Kalyuzhnyi, S. V., 2007. Kinetics of the degradation of aliphatic hydrocarbons by the bacteria Rhodococcus ruber and Rhodococcus erythropolis. Applied Biochemistry and Microbiology, 43(6): 587-592.

\section{How to cite this article:}

David Waikhom, Soibam Ngasotter, Laishram Soniya Devi, Manoharmayum Shaya Devi and Asem Sanjit Singh. 2020. Role of Microbes in Petroleum Hydrocarbon Degradation in the Aquatic Environment: A Review. Int.J.Curr.Microbiol.App.Sci. 9(05): 2990-2903. doi: https://doi.org/10.20546/ijcmas.2020.905.342 